\title{
Penerapan Zahir Accounting Dalam Transaksi Pembelian Barang PD. Mitrasarana Komputindo Pontianak
}

\author{
Latifah $^{1}$, Prianka Larasati ${ }^{2}$
}

\begin{tabular}{|c|c|}
\hline Info Artikel & ABSTRACT \\
\hline $\begin{array}{ll}\text { Diterima } & \text { Juni } 12,2020 \\
\text { Revisi } & \text { Juli 16, 2020 } \\
\text { Terbit } & \text { September 30, } 2020\end{array}$ & $\begin{array}{l}\text { Manually accounting processing has more risks compared using a } \\
\text { computerized system. For example, in the simplest terms of journal entry, } \\
\text { there is often a doubling, or twice the input with the same memorandum } \\
\text { number in different transactions. This make an imbalance of ledgers and } \\
\text { financial reports that are made later, this is what happens to PD. } \\
\text { Mitrasarana Komputindo which still uses the manual system in preparing its }\end{array}$ \\
\hline $\begin{array}{l}\text { Keywords: } \\
\text { Application of Accounting } \\
\text { Applications } \\
\text { Accounting Data Processing Zahir } \\
\text { Accounting Version 5.1 } \\
\text { Computer Store Transactions }\end{array}$ & $\begin{array}{l}\text { financial statements. Most of the data recording is using Microsoft Excel, } \\
\text { from customer and vendor data, account data, general journals till financial } \\
\text { reports. This can have an impact on financial statements ineffective and } \\
\text { requires a long time because all data is not directly related. The occurrence } \\
\text { of errors can also result in inaccuracies in the financial statements produced } \\
\text { and delays in finding the data needed. PD Mitrasarana Komputindo requires } \\
\text { an accounting application can make it easy to process financial data and } \\
\text { business decisions quickly and accurately. Then it can reduce errors that can } \\
\text { occur in processing financial data and if we want to find the data it will be } \\
\text { easier and faster than recording data in writing. Using Zahir Accounting } 5.1 \\
\text { version be an alternative in processing existing data, and expected to reduce } \\
\text { errors, both in the input and calculation process. }\end{array}$ \\
\hline
\end{tabular}

\section{Identitas Penulis:}

Latifah $^{1}$, Prianka Larasati ${ }^{2}$

Universitas Bina Sarana Informatika Program Studi Sistem Informasi Akuntansi Kampus Pontianak, Jalan Abdurrahman Saleh No.18 A Pontianak,

Email: latifah.lat@bsi.ac.id ${ }^{1}$, priankalarasati@gmail.com²

\section{PENDAHULUAN}

Akuntansi merupakan suatu proses mencatat, mengklasifikasi, meringkas, mengolah dan menyajikan data, transaksi serta kejadian yang berhubungan dengan keuangan sehingga dapat digunakan oleh orang yang menggunakannya dengan mudah dimengerti untuk pengambilan suatu keputusan serta tujuan lainnya [1].

Pengolahan akuntansi secara manual memiliki lebih banyak resiko dibandingkan denganmenggunakan sistem yang terkomputerisasi. Misal, dalam hal yang paling sederhana yaitu penginputan jurnal, seringkali terjadi penggandaan, atau dua kali input dengan nomor nota yang sama tapi transaksi yang berbeda. Hal ini dapat berakibat pada tidak balance-nya buku besar dan laporan keuangan yang dibuat nantinya, inilah yang terjadi pada PD. Mitrasarana Komputindo yang masih menggunakan sistem manual dalam membuat laporan keuangannya.

Berdasarkan pernyataan tersebut, maka dapat disimpulkan bahwa bidang akuntansi pun sangatmembutuhkan sistem yang terkomputerisasi didukung dengan pengetahuan teknologi informasi, maka bidang akuntansi dan teknologi informasi telah menciptakan berbagai macam software akuntansi salah satunya adalah Zahir Accounting.Konsep pengolahan data akuntansi menggunakan Zahir dapat dikatakan mudah, praktis, biaya murah, efektif dan efisien serta akurat (valid) karena hanya melakukan penginputan terhadap menu yang telah tersedia.Pengolahaannya tidak seperti manual yang memerlukan banyak waktu dan tahapan proses. Dalam akuntansi manual proses tahapan dimulai dengan pencatatan jurnal, penyusunan neraca saldo, pembuatan neraca lajur, penyusunan ayat penyesuaian, pembuatan laporan keuangan secara tahapan yang terpisah untuk laporan perhitungan rugi-laba, laporan perubahan modal dan neraca [4].

Zahir Accounting adalah salah satu peranti lunak akuntansi yang dikembangkan oleh putra bangsa Indonesia, hal ini merupakan salah satu penyebab Zahir Accounting menjadi perhatian para pengusaha di Indonesia. Zahir Accounting menjadi perhatian bagi para pengusaha yang memerlukan software akuntansi untuk menunjang pencatatan keuangan bisnisnya dengan mudah,cepat dan tepat [2].

PD. Mitrasarana Komputindo yang merupakan perusahaan dagang yang menjual berbagai macam komputer, laptop dan juga smartphone yang kegiatannya melakukan transaksi penjualan dan pembelian. Adanya kendala atau masalah yang dikarenakan penggunaan sistem yang masih manual antara lain seperti: banyaknya penggunaan kertas, kesulitan menyimpan arsip yang kadang sering hilang, membuat data excel 
yang cukup rumit. Sehubungan dengan masalah dari kendala diatas, maka penulis mencoba mempelajari sistem akuntansi manual yang masih dipakai pada PD. Mitrasarana Komputindo hingga diterapkan ke aplikasi Zahir versi 5.1 ini.

Dengan semakin berkembangnya kemajuan teknologi informasi, banyak perusahaan tidak lagi melakukan pencatatan akuntansi secara manual, tetapi dilakukan dengan bantuan program komputer atau disebut dengan program aplikasi akuntansi. Dengan menggunakan program aplikasi akuntansi proses akuntansi dapat diringkas menjadi lebih singkat, karena beberapa proses pencatatan sudah secara otomatis dilakukan komputer (program) [3].

\section{METODE}

Di dalam penelitian ini, dibahas penerapan Zahir versi 5.1 pada transaksi PD. Mitrasarana Komputindo dengan membatasi penulisan pada transaksi-transaksi yang terjadi lalu mengaplikasikan ke dalam aplikasi Zahir Accounting 5.1 dari mulai membuat data perusahaan baru, pembuatan akun, pembuatan saldo awal, pengelolahan transaksi seperti adanya pembelian dan penjualan barang secara kredit maupun tunai hingga menyajikan laporan keuangan. Pengolahan transaksi seperti adanya pembelian barang secara kredit maupun tunai.

Tools aplikasi yang digunakan adalah Zahir Accounting Versi 5.1, merupakan sebuah program akuntansi yang fleksibel berfasilitas lengkap dan berdaya guna tinggi, yang dirancang untuk sistem operasi windows 98 atau 2000 atau XP atau Vista. Aplikasi ini dibangun dengan konsep bahwa akuntansi keuangan mudah dan menggunakan aplikasi keuangan adalah sebuah pengalaman yang menyenangkan. Selain kemudahan dalam mencatat transaksi - transaksi dan pembuatan laporan keuangan tanpa hanya mempelajari teori akuntansi keuangan Zahir Accounting Versi 5.1.

\section{HASIL}

Untuk mengatasi permasalahan yang sering terjadi pada penjualan secara tunai PD. Mitrasarana Komputindo adalah sebagai berikut:

1. Dibuat sebuah sistem yang terkomputerisasi karena dengan aplikasi akuntansi Zahir tersebut dapat menyelesaikan pekerjaan secara efektif dan efisien. Dengan demikian dapat mengurangi kesalahankesalahan yang terdapat dalam sistem seperti kesalahan dalam penginputan, perhitungan dan penyimpanan berbagai data yang penting.

2. Membuat database agar semua data penjualan dapat tersimpan dengan baik, yang memudahkan dalam pengecekan data, dapat menampung lebih banyak data dan informasi, serta proses pemasukan dan penyimpanan data dapat diakses dengan cepat dan mudah.

a. Saldo Awal Akun

Langkah-langkah mengisi saldo awal di neraca saldo adalah sebagai berikut:

1) Pada toolbar Zahir Accounting, klik Setting pilih saldo awal - lalu pilih Saldo Awal Akun

\begin{tabular}{l} 
Q. Zahir Standard Edisi Pendidikan 5.1 - September 2019 - cildata zahirlpd. mitrasa \\
\hline E. File Setting Plugin Tutup Buku Window [F1] Petunjuk \\
\hline Sasifikasi Akun \\
\hline Saldo Awal
\end{tabular}

Sumber : Aplikasi Akuntansi Zahir

Gambar 1. Tampilan Setting Saldo Awal Akun 
2) Isi saldo awal akun jika sudah selesai kemudian klik tombol Rekam

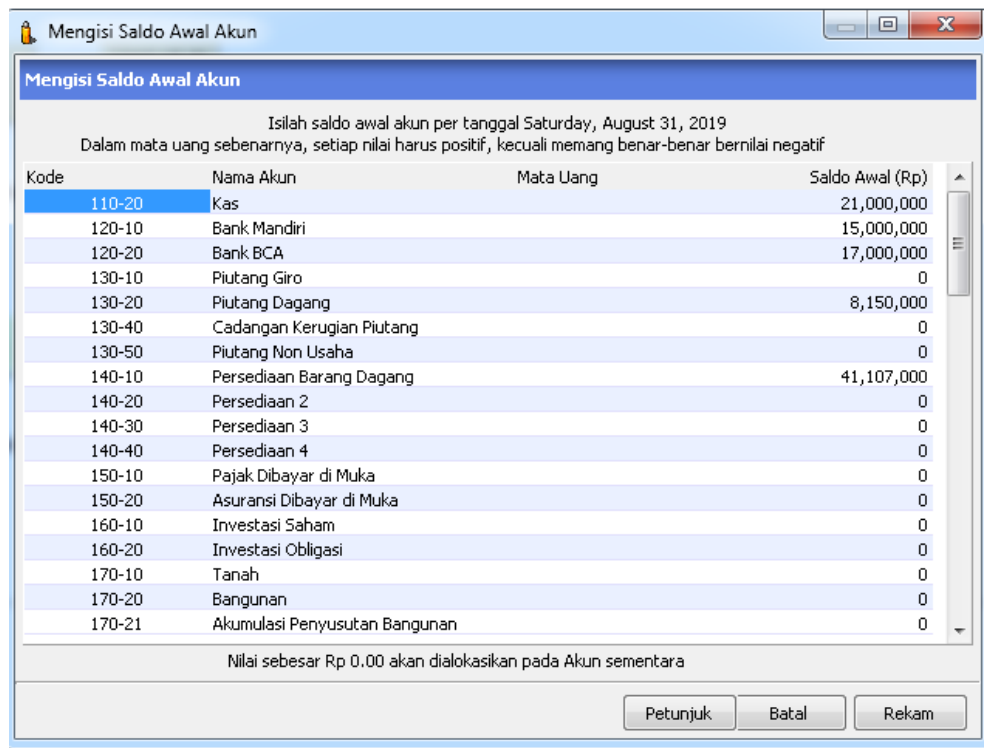

Sumber : Aplikasi Akuntansi Zahir

Gambar 2 Tampilan Saldo Awal Akun

Untuk membuka laporan dari transaksi yang telah dibuat bisa menggunakan langkah-langkah seperti ini: Buka modul laporan - pilih laporan keuanga, maka otomatis transaksi yang sudah di input akan kelihatan pada laporan keuangan yang dipilih pada PD. Mitrasarana komputindo di dapat output laporan keuangan seperti dibawah ini, meliputi : jurnal kas masuk, jurnal kas keluar, buku besar, neraca saldo dan laporan laba rugi.

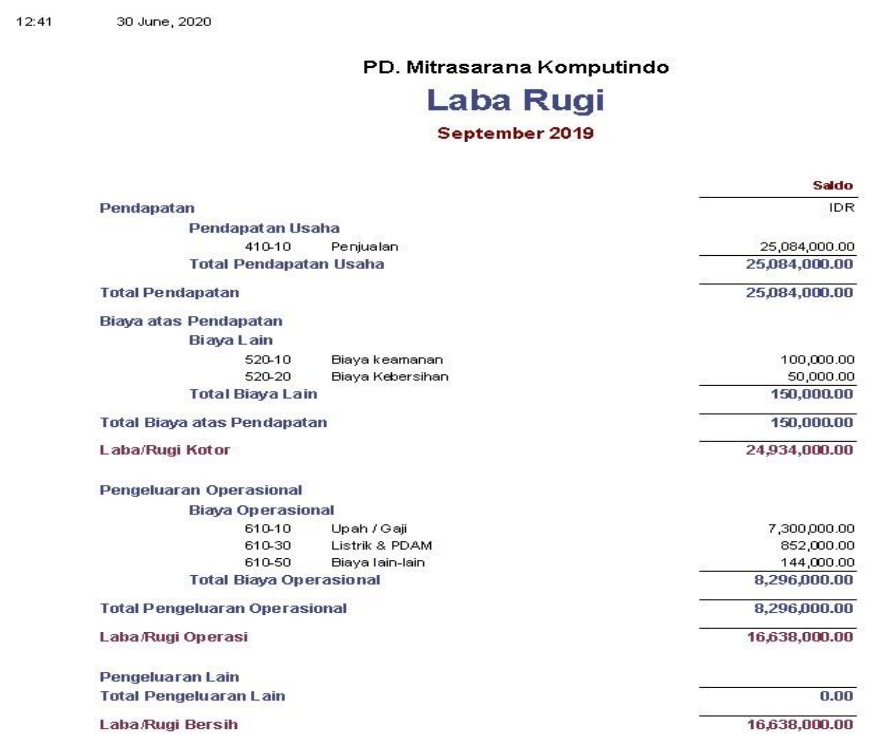


Sumber : Aplikasi Akuntansi Zahir

\section{Gambar 3. Output Neraca standar}

Analisis laporan keuangan adalah suatu proses penelitian laporan keuangan beserta unsur-unsurnya yang bertujuan untuk mengevaluasi hasil-hasil yang telah dicapai oleh perusahaan. Untuk menampilkan analisis laporan keuangan pada aplikasi Zahir dengan cara klik modul 'Laporan', kemudian pilih Analisa Bisnis. Kemudian akan muncul berbagai grafik seperti gambar di bawah.

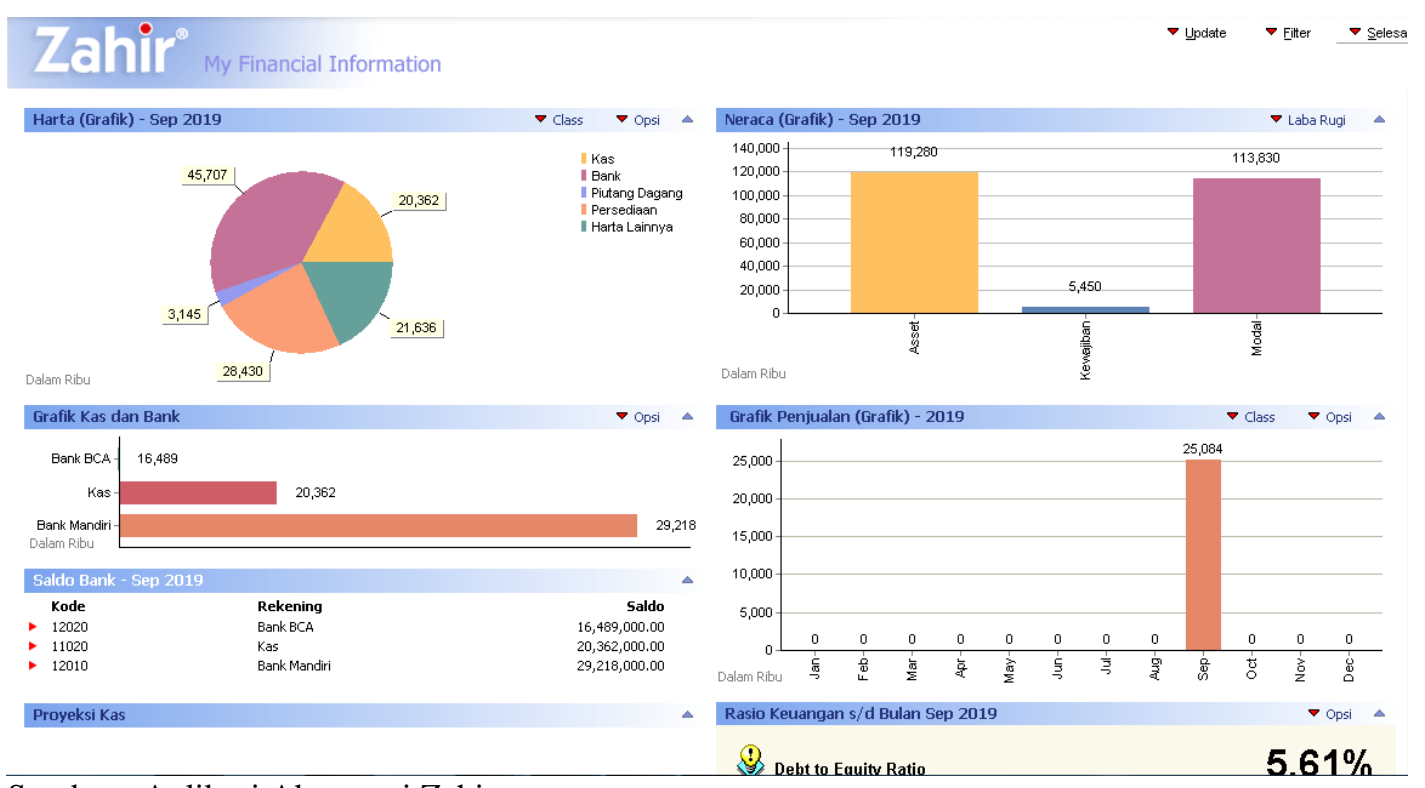

Sumber : Aplikasi Akuntansi Zahir

\section{Gambar 4. Analisis Laporan Keuangan}

Tabel 1. Analisa Keuangan Pada Zahir

\begin{tabular}{|l|}
\hline 1. Rasio Liquiditas \\
\hline Current Ratio : $1,791.63 \%$ \\
\hline Cash Ratio : $1,212.28 \%$ \\
\hline Acid Test Ratio : $1,269.98 \%$ \\
\hline Working Capital to Total Asset $: 77.29 \%$ \\
\hline Perputaran Piutang : $15.95 x$ \\
\hline 2. Rasio Solvabilitas / Leverage \\
\hline Total Debt to Equity Ratio : $5.61 \%$ \\
\hline Total Debt to Total Capitas Asset Ratio : $4.57 \%$ \\
\hline Long Term Debt to Equity Ratio : 0.00\% \\
\hline Long Term Debt to Total Asset Ratio : $0.00 \%$ \\
\hline 3. Rasio Profitabilitas \\
\hline Return On Equity : $17.12 \%$ \\
\hline Gross Margin : $99.40 \%$ \\
\hline Net Margin : $66.33 \%$ \\
\hline Operating Ratio : $33.67 \%$ \\
\hline
\end{tabular}

Sumber : Aplikasi Akuntansi Zahir

\subsection{Rasio Liquiditas}

1. Current Ratio

Merupakan perbandingan antara aktiva lancar dengan hutang lancar Ini berarti setiap satu Rp hutang lancar dijamin oleh Rp 17,92 aktiva lancar. Rumus: Aktiva Lancar / Hutang Lancar x 100\% adalah 97.644.000/ 5.450.000 x $100 \%=1,791.63 \%$. 
Rasio Keuangan s/d Bulan Sep 2019

Current Ratio

Rasio yang menyatakan perbandingan antara aktiva lancar dengan hutang lancar.

Ini berarti setiap satu Rp hutang lancar dijamin oleh Rp 17.92 aktiva lancar.

Chart $\nabla$ Opsi $\triangle$

\section{$1,791.63 \%$}

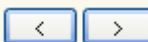

Sumber : Aplikasi Akuntansi Zahir

2. Cash Ratio

\section{Gambar 5. Current Ratio}

Perbandingan antara jumlah kas dan efek terhadap hutang lancar, menyatakan kemampuan sesungguhnya dalam memenuhi hutang jangka pendek tepat waktu. Ini berarti setiap satu Rp hutang lancar dijamin oleh Rp 12.12 kas dan efek. Rumus: Kas + Efek / Hutang Lancar x 100\% adalah 20.362.000 + 45.707.000 / $5.450 .000 \times 100 \%=1,212.28 \%$.

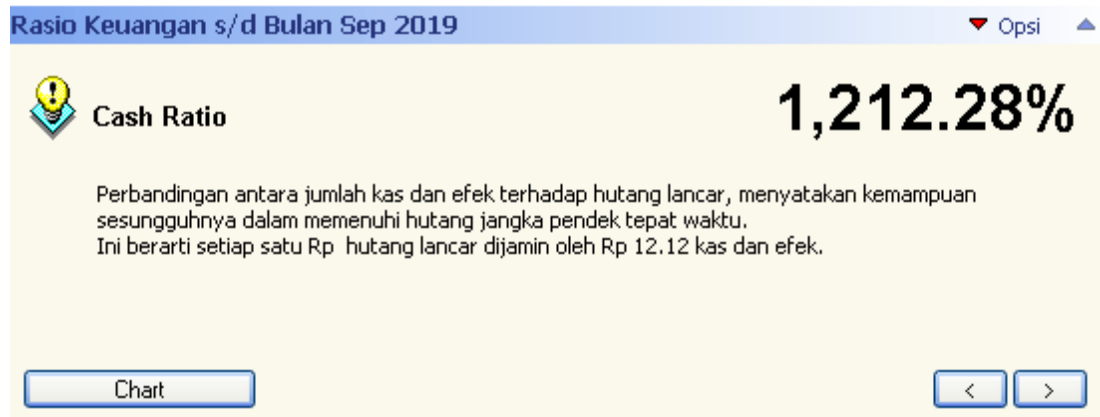

Sumber : Aplikasi Akuntansi Zahir

\section{Gambar 6. Cash Ratio}

3. Acid Test Ration

Merupakan perbandingan antara jumlah kas, efek, dan piutang terhadap hutang lancar. Rumus : Kas + Efek + Piutang / Hutang Lancar x 100\% adalah 20.362.000 + 45.707.000 + 3.145.000/ 5.450.000 x $100 \%=1,269.98 \%$.

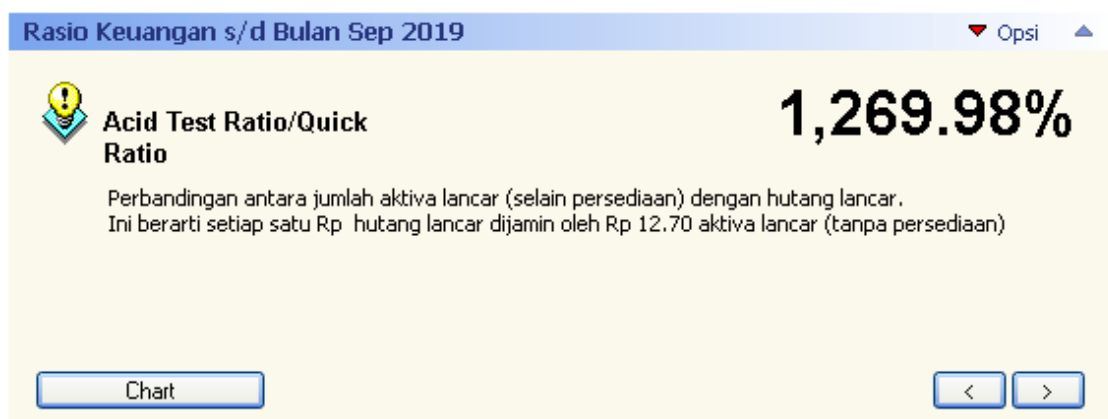

Sumber : Aplikasi Akuntansi Zahir

\section{Gambar 7. Acid Tes Ratio}

4. Working Capital to Total Asset

Merupakan perbandingan antara harta lancar dikurangi hutang lancar terhadap total asset (harta yang dimiliki). Rumus : Aktiva Lancar- Hutang Lancar / Total Aktiva x 100\% adalah 97.644.000 - 5.450.000 / $119.280 .000 \times 100 \%=77,29 \%$. 


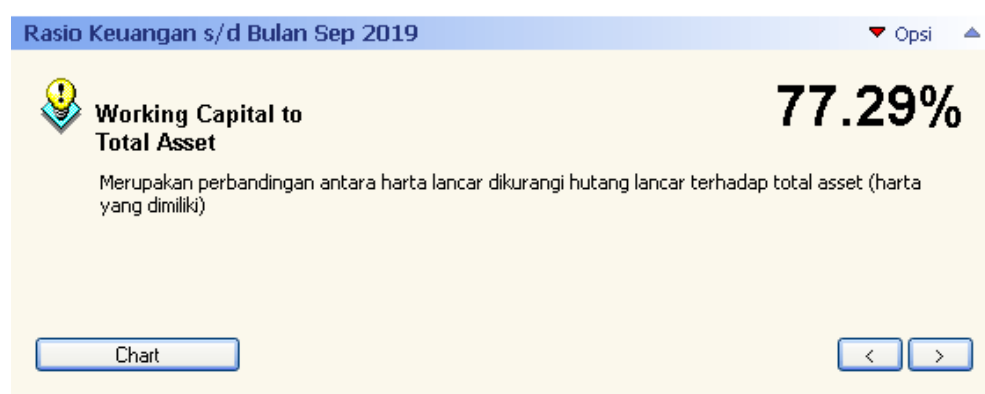

Sumber : Aplikasi Akuntansi Zahir

Gambar 8. Working Capital to Total Assets

\section{KESIMPULAN}

PD. Mitrasarana Komputindo adalah sebuah perusahaan yang bergerak dibidang dagang diantaranya: peralatan komputer, serta smartphone. Namun dalam proses penginputan transaksi hingga pembuatan laporan PD. Mitrasarana Komputindo masih menggunakan sistem manual dan belum terkomputerisasi. Berdasarkan tinjauan bab-bab sebelumnya, maka dapat ditarik kesimpulan bahwa Penggunaan Zahir Accounting 5.1 dapat menjadi alternatif pemecahan masalah dalam pengolahan data yang ada, dan diharapkan dapat mengurangi kesalahan- kesalahan, baik kesalahan dalam proses penginputan maupun kesalahan dalam proses perhitungan yang dilakukan oleh PD. Mitrasarana Komputindo. Dengan penerapan Zahir Accounting 5.1 dapat mempercepat proses pembuatan laporan serta memudahkan dalam pencarian data, dan untuk menyimpan data pun lebih aman.

\section{UCAPAN TERIMA KASIH}

Terima kasih kepada Mitrasarana Komputindo Pontianak yang telah bersedia memberikan data dan menerima pengajuan riset untuk aplikasi Zahir. Terima kasih pula kepada jajaran civitas akademika Universitas Bina Sarana Informatika serta redaksi Justian dalam penerbitan artikel ini.

\section{REFERENSI}

[1] Desmahary, Y., \& Kuswara, H. (2016). Aplikasi Akuntansi Zahir Accounting Untuk Pengolahan Data KeuanganPada PD. Nugraha Jakarta. Jurnal Online Insan Akuntan.

[2] Ida, F., Aryanto, A., \& Sunandar, S. (2018). ZAHIR ACCOUNTING. In DIKEMAS (Jurnal Pengabdian Kepada Masyarakat). https://doi.org/10.32486/jd.v2i2.283

[3] Mulyaningsih, T., Faizah, S., \& Solecha, K. (2018). Pengolahan Data Akuntansi Perusahaan Dagang Menggunakan Zahir Accounting Versi 5.1. In INFORMATION MANAGEMENT FOR EDUCATORS AND PROFESSIONALS. https://doi.org/10.30871/jaemb.v5i2.537

[4] Zaenuri, M. (2013). Penerapan Aplikas Software Myob Pada Perusahaan Dagang ( Toko Angkasa Komputer ). In Infokam, Yogyakarta. 